Creative Commons User License: CC BY-NC-ND

Abstracted by: EBSCOhost, Electronic Journals Service (EJS),

Google Scholar, Journal Seek, Scientific Commons,

Food and Agricultural Organization (FAO), CABI and Scopus

http://eoi.citefactor.org/10.11226/v25i1
Journal of Agricultural Extension

Vol. 25 (1) January, 2021

ISSN(e): 24086851; ISSN(Print); 1119944X

http://journal.aesonnigeria.org

http://www.ajol.info/index.php/iae

Email: editorinchief@aesonnigeria.org

\title{
Sasakawa Africa Fund for Extension Education: A Review of Demand-Driven Agricultural Extension Education in Nigeria https://dx.doi.org/10.4314/jae.v25i1.9
}

\author{
Oladele Idowu \\ Sasakawa African Fund for Extension Education Nigeria/ Ethiopia \\ Oladele20002001@yahoo.com +2348148768261.
}

\begin{abstract}
The paper examined demand-driven agricultural extension education in Nigeria and emphasized the need for extension professionals to acquire soft skills in addition to their technical capabilities through the utilization of demand-driven extension education (DDEE) strategies. A review of demand-driven agricultural extension education in Nigeria as introduced by Sasakawa Africa Fund for Extension Education in universities was carried out to assess the concepts of demand-driven extension education, capacity development, skill, skill- mismatch. The reviews were analysed using themes and the findings were reported based on the themes identified from the review analysis. Job matching and human capital theories are the theoretical underpinning for this paper. The paper further highlighted the numerous benefits of DDEE prominent among which include its ability to adapt to the need of the learners and employers, utilize dynamic work-based pedagogy to improve competencies, and respond to the needs of the labour markets to ensure continuous alignment between desired qualification and available training. It is important to properly mainstream the use of demand-driven extension education strategies in training extension personnel for better and more sustainable extension and services delivery to farmers.
\end{abstract}

Keywords: Agricultural extension, agricultural education, demand-driven extension education, capacity development, skill, skill- mismatch

\section{Introduction}

A major purpose for the delivery of agricultural extension has been towards significant contribution to reduction of poverty and social inequalities, ensuring food security, sustainable use of natural resources, through participatory development. Agricultural extension is a common denominator for agricultural development, agribusiness development, functional value-chain and food security such that agricultural development outcomes are closely linked to the agricultural advice provided by extension services. World Bank (2015) indicated that growth originating from agriculture (through extension services) has been two to four times more effective at reducing poverty than growth originating from other sectors. "Investing in extension so that it helps more farmers in more places - women as well as men, smallholders as well as commercial farmers - is the only way to reap the full benefit of innovation" (Gates, 2015). Ragasa and Mazunda (2018) stated that households 
Creative Commons User License: CC BY-NC-ND

Abstracted by: EBSCOhost, Electronic Journals Service (EJS),

Google Scholar, Journal Seek, Scientific Commons,

Food and Agricultural Organization (FAO), CABI and Scopus

http://eoi.citefactor.org/10.11226/v25i1
Journal of Agricultural Extension

Vol. 25 (1) January, 2021

ISSN(e): 24086851; ISSN(Print); 1119944X

http://journal.aesonnigeria.org

http://www.ajol.info/index.php/iae

Email: editorinchief@aesonnigeria.org

in Malawi that reported receipt of "very useful" agricultural advice had greater productivity and greater food security compared to those that reported receipt of advice that they considered not useful and those that did not receive any advice at all as well as those that received fertilizer and seed subsidies only.

From inception, agricultural extension services (AES) have been supply driven because it is regarded as public-good due to government involvement as the major financier and supplier. Overtime with the advent of commodity-based extension approach, AES as a private-good emerged based on the principles of excludability and exclusiveness of AES. The poor performance of agricultural extension has been attributed to governance failures such as low priority and support for extension; bureaucratic procedures; top-down decision-making and low farmer participation in extension planning and implementation; strong upward accountability toward bureaucratic hierarchies and donors, weak downward accountability to users of extension services (farmers), poor performance incentives for public extension officers; weak interaction with agricultural research; misuse of extension officers for political purposes and patronage by local agencies along ethnic or religious lines (Ragasa, Ulimwengu, Randriamamonjy \& Badibanga 2016).

In response to governance failures of agricultural extension, there have been introduction of different extension approaches and models such as decentralization, institutional arrangements, and donor induced patterns which consequently, have brought many role players to the landscape of extension delivery. These role players have varied backgrounds, qualifications, trainings, field experiences and subject matter specializations, and their involvement in extension delivery is often depicted as pluralism in extension services. The influx of several role players both in types and numbers in the AES delivery had been with several approaches and models which often is described as pluralistic although true pluralism refers to coordinated, harmonized, regulated activities of different players in the AES delivery landscape. Kaur et al. (2015) noted that pluralistic extension system is driven by the privatization of the agricultural extension system. The pluralistic extension services scenario in Nigeria can be described in terms of several role players and methodologies for extension delivery. In Nigeria, the broad typologies of extension service provision include:

- programme (duration specific) - Donor sponsored, government sponsored, regional, national, continental sponsored;

- commodity based extension services - arable, cash, tree, irrigation, livestock;

- organizational type (governance specific) - governmental NGO and international NGO, input dealers;

- mode of delivery (tools of service delivery) - ICT, extension agent, combination; and

- Private farms and commercial producers (individual, group and commercial farming)

For each of the modalities of the prevailing extension services delivery in Nigeria, there are multiplicity of players in services provision to end users and many times 
Creative Commons User License: CC BY-NC-ND

Abstracted by: EBSCOhost, Electronic Journals Service (EJS),

Google Scholar, Journal Seek, Scientific Commons,

Food and Agricultural Organization (FAO), CABI and Scopus
Journal of Agricultural Extension

Vol. 25 (1) January, 2021

ISSN(e): 24086851; ISSN(Print); 1119944X

http://journal.aesonnigeria.org

http://www.ajol.info/index.php/jae

Email: editorinchief@aesonnigeria.org

overlapping in contents and coverage with little or no form of regulation with respect to what is actually delivered to end-users. In the public administrative setting of Nigeria, there are exclusive but not exhaustive list of extension service providers such as 44 agricultural research institutes, 30 national agencies/ parastatals on agriculture, 36 states agencies for agricultural development, 77 faculties of agriculture, 3 specialized universities of agriculture which are interfacing with several NGOs and international NGOs serving the end-users within the same time and space. The multiplicity of actions and roles are often described as collaboration, but a systematic analysis reveals the lack of proper application of pluralistic extension processes as it oftentimes depicts role players' resource seeking and attribution. There are over 100 prominent NGOs involved in agricultural extension services in Nigeria, which has implications for adequate, accurate and accessible information and technology towards achieving food security.

Pluralism of AES delivery, advent of ICT and globalization processes particularly trade as well as changing consumers' needs and preferences in terms of quality, standards, safety and health along the value chain have led to farmers demanding more in areas required by the market forces. The concept of demand-driven extension emphasizes the need to provide services that meet the needs and priorities of farmers, even if the market mechanism fails to make sure that extension services are supplied in the quantity and quality expected by farmers (Khondokar, Knierim, Chowdhury 2020) ). Demand-driven extension services is the articulation of services required to meet the necessary information, skills and competencies in response to needed goods and services. On the farmers' side, the demands from farmers are in many cases, a reflection of the demands being made on farmers themselves by other value-chain actors. The demands on farmers may consist of commodity quality and quantity, food safety standards as well as official regulations. GFRAS (2015) reported that demand articulation, service provision, and financing are key elements of agricultural extension servcies to which producer organisations contribute, often in collaboration with other actors. Processes of developing demandorientation frequently include identification of individual needs, prioritisation of ideas, formulation and articulation of demands, negotiation of rural advisory services, monitoring and evaluation of delivered extension services.

The demand on farmers has also led to demand on extension service providers hence extension education in terms of training and capacity development of the extension service providers by universities and colleges. Demand-driven education has been variously depicted as competency-based education and career-ready education. Competency-based education (CBE) programmes enhance learner's advancement by demonstrating mastery of specific competencies through practical assessments, rather than by completing a traditional, time-bound course while on the other hand, the term career-ready is generally applied to: (1) students who are considered to be equipped with the knowledge and skills deemed to be essential for success in the modern workforce, or (2) the kinds of educational programmes and learning opportunities that lead to improved workforce preparation. The career-ready concept is also related to 21st century skills and college-ready. Blumenstyk (2019) 
Creative Commons User License: CC BY-NC-ND

Abstracted by: EBSCOhost, Electronic Journals Service (EJS), Google Scholar, Journal Seek, Scientific Commons,

Food and Agricultural Organization (FAO), CABI and Scopus

http://eoi.citefactor.org/10.11226/v25i1
Journal of Agricultural Extension

Vol. 25 (1) January, 2021

ISSN(e): 24086851; ISSN(Print); 1119944X

http://journal.aesonnigeria.org

http://www.ajol.info/index.php/jae

Email: editorinchief@aesonnigeria.org

stated that career ready education has to go beyond skill gaps as hiring has become skills-based, alternative credentials gain traction, and more jobs go digital.

\section{Steps-in-Introducing Sasakawa Africa Fund for Extension Education (SAFE) Demand Driven Curriculum to Universities}

To ensure the strategies for demand-driven education in the agricultural extension training in Nigeria, Sasakawa Africa Fund for Extension Education (SAFE) introduced demand-driven curriculum to universities. According to SAA (2018), Sasakawa Africa Association (SAA) is an international agricultural development nongovernmental organization, established in 1986 by Norman Borlaug, Ryoichi Sasakawa and Jimmy Carter and has been working on agricultural programs in 15 sub-Saharan countries but currently focusing on four countries (Ethiopia, Nigeria, Mali and Uganda), although the University component of Sasakawa Africa Fund for Extension Education covers Malawi, Benin, Tanzania, Burkina Faso and Ghana in addition to the four focus countries in the area of human capital development. SAA works with national partners to improve the productivity and profitability of smallholder farmers by building their capacities along the entire agricultural value chain. SAA agricultural extension work relies on a strategic partnership building with a broad array of public and private development actors such as government agricultural extension and advisory service providers, research institutions, universities and agricultural colleges, business service providers, smallholder farmers and their organizations, agricultural input and output agro-dealers, processors and others operating along the agricultural value chain.

SAA (2018) stated that SAA thematic areas are crop productivity enhancement (CPE), postharvest handling \& agro-processing (PHAP) and business development. The theme on Sasakawa Africa Fund for Extension Education (SAFE) was established in 1991 to contribute to building the institutional capacity of African universities and agricultural colleges to offer appropriate training in agricultural extension. Through SAFE, partner universities and agricultural colleges provide incountry, demand-driven training programs. Mid-career extension agents are equipped with the necessary knowledge, skills and competencies to effectively and efficiently disseminate crucial agricultural information and technology to farmers. Currently, SAFE is mainstreaming value chain into curriculum of 26 universities in the training of mid-career extension personnel in 11 countries of Africa (SAA, 2018).

A different format of training from the conventional Bachelor's Degree programme in agricultural extension, the SAFE component carries out the formal training in the universities and agricultural colleges through demand-driven curriculum, Supervised Enterprise Projects (SEPs) and Enterprise Centres (Ghimire, 2017 ). SEPs is an insitu tool for capacity development and technology transfer. The candidate develop capacity (knowledge and skills) on the specific technology in question and simultaneously transfer technology to the community. It is underpinned by action research principles and theory but the sequence of activities in SEPs is uniquely different from other action research approaches in agriculture. SEPs has learning and development dimensions that includes multi-stakeholder platform, extension 
Creative Commons User License: CC BY-NC-ND

Abstracted by: EBSCOhost, Electronic Journals Service (EJS),

Google Scholar, Journal Seek, Scientific Commons,

Food and Agricultural Organization (FAO), CABI and Scopus
Journal of Agricultural Extension

Vol. 25 (1) January, 2021

ISSN(e): 24086851; ISSN(Print); 1119944X

http://journal.aesonnigeria.org

http://www.ajol.info/index.php/jae

Email: editorinchief@aesonnigeria.org

technology transfer, community development, enterprise development and learning and sharing. Kalule et al, (2019) stated that faculty supervision support to students is critical to fostering lasting learning relationships in university outreach and thus, the needs to be a part of higher education sector for improved community linkages and innovation. The enterprise center is a space where innovation development and dissemination processes are explored by students, farmers, lecturers and researchers for training and practice purposes with emphasis on commodity value chain activities and skill acquisition. The main focus of SAA activities in four countries has been through thematic focus using various extension approaches to reach various actors along the value chain and working with National government and National extension systems to improve extension delivery to smallholder farmers.

\section{Objective of the study}

This paper described and contextualized demand-driven agricultural extension education in Nigeria as introduced by Sasakawa Africa Fund for Extension Education in universities

\section{Methodology}

A review of demand-driven agricultural extension education in Nigeria as introduced by Sasakawa Africa Fund for Extension Education in universities was carried out to assess the concepts of demand-driven extension education, capacity development, skill, skill- mismatch using on-line scholarly and scientific databases as well as more general search engines such as Google. The documents reviewed were from both peer-reviewed academic sources as well as project documents and other grey literature. Validity was ensured through triangulation with individuals, groups, and organisations (Santos, Ribeiro, Cristina, Silva, Ivisson, \& Ferreira. 2020). Debriefing with peers, member checks, and using expert consultants also helped to ensure validity (Figg, Wenrick, Youker, Heilman, Schneider (2020). Triangulation also helped to ensure reliability. The reviews were analysed using themes. The findings were reported based on the themes identified from the review analysis.

\section{Demand-Driven Education}

Demand-driven education places emphasis on making sure graduates are job-ready and in position to achieve their dream career goals. Demand-driven education focusses on the needs of the learner and the employer. It ensures that there is alignment between desired qualifications and available training as required by the society. Demand-driven education explores technology-infused, gig-oriented, industry-driven skills and ensure that new graduates and lifelong learners have the skills required to flourish. Demand driven extension education develops and measures the specific skills that are mostly demanded; utilizes dynamic and workbased pedagogy to improve competencies, responds to the needs of the labour markets to ensure continuous alignment; creates pathways to allow learners to rapidly convert learning to earning; supports changes that make the entire education 
Creative Commons User License: CC BY-NC-ND

Abstracted by: EBSCOhost, Electronic Journals Service (EJS),

Google Scholar, Journal Seek, Scientific Commons,

Food and Agricultural Organization (FAO), CABI and Scopus

http://eoi.citefactor.org/10.11226/v25i1
Journal of Agricultural Extension

Vol. 25 (1) January, 2021

ISSN(e): 24086851; ISSN(Print); 1119944X

http://journal.aesonnigeria.org

http://www.ajol.info/index.php/jae

Email: editorinchief@aesonnigeria.org

landscape function better, and creates the future of education alongside industry (Deegan \& Martin, 2017).

Winfrey (2015) stated that agricultural education and training must be local and demand-driven in response to the projections by the World Bank (2015) that agriculture and agribusiness will be a $\$ 1$ trillion industry in sub-Saharan Africa by 2030 . Growing urban markets are demanding a greater diversity of value-added food products, opening windows of opportunity for innovation.

\section{Skills Matching}

Several authors have defined and explained the concept of skill as; as "any combination, useful to industry, of mental and physical qualities which require considerable training to acquire"; "the innate or learned ability to apply the knowledge acquired through experience, study, practice or instruction, and to perform tasks and duties required by a given job" and "a worker's endowment of capabilities for performing various tasks". The correct match of a worker's skills to the job requirements leads to the efficient use of the existing labour force potential (OECD 2018 and Stoevak 2017).

Demand-driven extension education ensures that skill types, level and contents are developed. Skill type refers to a number of skills that are grouped together due to their common characteristics or qualities; which can be core skills, industry-specific skills, and occupation or job-specific skills. Skill level means the position of skills which is assigned to a rank depending on its complexity and difficulty and performance level such as education level, grade level of qualification level, certification level and national qualification framework (Uh et al., 2015, Berger and Frey (2015)). Skill content is the specific component, composition and specialization of skills needed in an occupation (OECD, 2018).

The Society for Human Resource Management (SHRM) (2016), reported that from a survey of over 1000 recruiting agencies, a major reason organizations have difficulty in hiring full-time regular positions is candidates not having the needed training. The search for the improvement of performance before and after recruitment exercises and job placement have always been critical of employability skills. A high-quality workforce is the most important determinant of business success; these challenges have a direct influence on organizations' competitiveness both today and in the future. Job fit refers to the degree to which job characteristics that an individual worker performs and the knowledge, skills, and capacities necessary for job performance correspond or are appropriate (OECD, 2018).

\section{Job Matching and Human Capital Theory}

The theories underlying this paper are job matching theory and human capital theory. The job matching theory states that a mismatch between the required skills and the skills a graduate actually possesses has important consequences for productivity, wages and probability to get a job (Kojima, Sun and Yu, 2020). . The human capital theory refers to the aggregate stock of competencies, knowledge, 
Creative Commons User License: CC BY-NC-ND

Abstracted by: EBSCOhost, Electronic Journals Service (EJS),

Google Scholar, Journal Seek, Scientific Commons,

Food and Agricultural Organization (FAO), CABI and Scopus

http://eoi.citefactor.org/10.11226/v25i1
Journal of Agricultural Extension

Vol. 25 (1) January, 2021

ISSN(e): 24086851; ISSN(Print); 1119944X

http://journal.aesonnigeria.org

http://www.ajol.info/index.php/jae

Email: editorinchief@aesonnigeria.org

social, and personal attributes embodied in the ability to create intrinsic and measurable economic value (Marginson, 2019). Demand-driven education prevents the incidence and prevalence of skill mismatches that predominate agricultural extension service delivery in Africa (Oladele, 2019). Qualitative mismatches arise when the qualifications of workers, individually or in the aggregate, are different from the qualifications required or specified for their jobs. Quantitative mismatches arise when there is a gap in the supply and demand for specific skills. Field-of-study mismatch occurs when a worker, trained in a particular field, works in another field. Conceptually and empirically, field-of-study mismatch is distinct from qualifications mismatch in that a worker may be matched to the job in terms of the quantity of schooling received (qualification match) but not by the type of schooling received (Montt, 2017); thus field-of-study mismatch is a form of horizontal mismatch while qualification mismatch is a form of vertical mismatch (OECD, 2016). Workers' qualifications and field-of-study are proxies for their skill set. They are imperfect indicators of the more specific skill mismatch, whereby workers' actual skills are measured against the specific skill requirements of the job (OECD, 2016).

\section{Skills Mismatch}

Skills mismatches become one of the major challenges for the public policy on the labour market. Lack of the proper match of skills, leads to inefficiencies in the labour market that should be limited, through appropriately designed public policies. Skill mismatch refers to when the supply of skills and the demand for skills could be out of sync in either direction (Cappelli, 2015). It is the difference in the actual skills that are possessed by an individual and the skills required in a job in terms of skills levels, type, and content. When a particular skill level is unmatched, it is called vertical mismatch (Schweri, Eymann \& Aepli (2020), and when the level is insufficient, it is referred to as skill gap (McGuinness and Ortiz, 2016). Horizontal mismatch is a type of mismatch that occurs when a certain type of skill that is demanded is unmatched, and this includes specific type of skills that is encapsulated in a degree major or field of study (Schweri, Eymann \& Aepli (2020). Mismatched workers will not be able to use their field-specific skills on the job, and their employers will not reward these skills. Field-of study mismatched workers are thus expected (and do in general) earn lower salaries when compared to their well-matched peers (McGuinness and Ortiz, 2016). The causes of skill mismatch include incomplete information on the labour market, education and training system problems, inadequate investment in training and education and lack of intersectoral or interregional mobility (Gambin et al., 2016),

\section{Importance of Demand-driven Extension Education}

Agricultural extension services requires specific skills at different level for effective extension services. Suvedi et al (2018) stated the 48 competencies representing eight core competencies that agricultural advisor and extension officers require high competency in for effective performance. The acquisitions of these skills go beyond the minimal 2 or 3 modules or courses in the general college or university curriculum. ICAR (2017) stated that: "Graduates are required to possess professional capabilities to deal with the concerns of sustainable development (productive, 
Creative Commons User License: CC BY-NC-ND

Abstracted by: EBSCOhost, Electronic Journals Service (EJS),

Google Scholar, Journal Seek, Scientific Commons,

Food and Agricultural Organization (FAO), CABI and Scopus
Journal of Agricultural Extension

Vol. 25 (1) January, 2021

ISSN(e): 24086851; ISSN(Print); 1119944X

http://journal.aesonnigeria.org

http://www.ajol.info/index.php/jae

Email: editorinchief@aesonnigeria.org

profitable and stable) of agriculture in all aspects. Furthermore, there is need for agricultural graduates to possess knowledge skills, including 'soft skills' (e. g: written and verbal communication ability and also entrepreneurship) to provide a class of village-based services such as advisories on new innovations, markets and avenues of development assistance for corporate and contract farming." "Extension workers must know and understand the content of their disciplines well enough to teach it to someone else and respond to questions about its underlying assumptions and theories." Hailemichael and Haug (2020) found that in Ethiopia development agents were competent in technical subject areas but need training in extension approaches and communication skills. Also, Cho, Robalino, and Watson, (2016) found that a combination of skills, mechanisms, supportive and collaborative systems with focus on self-employment and entrepreneurship should be considered in order to improve students' situation for labour market. Furthermore, Davis (2015) stated that "extension agents have a set of competencies that are special and separate from other disciplines; although focus have been on the technical rather than the functional aspects", the study examined the pervasiveness of qualitative and quantitative skills mismatch in agricultural extension services. Finally, Winfrey (2015) reported that based on the interviews and focus groups conducted in six of the 19 countries on which Feed the Future is currently focusing, and employers consistently say from country to country: no matter the technical expertise sought, soft skills are needed in addition to technical capacities.

\section{Strategies for Demand-driven Education}

Some of the strategies for demand driven education include the use of:

- Competency-based education, which allows learners to show what they know as soon as they know it and move quickly to the next level;

- Employer and industry-led models, which radically lower the opportunity costs of education by providing further training on the job;

- The latest labour market intelligence tools and techniques, which provide educators with powerful insights into the changing skills marketplace;

- Dynamic and work-based pedagogy, to instil the critical skills needed for the future of work;

- New pathways and business models that support access and completion for learners at any point in their career and at virtually any income level;

- Theme-based academies and dual-enrolment programmes, integrating academic preparation with career-related learning experiences; and

- Recognizing credit for prior learning and alternative credentials (certificates, which are earned by completing a program of study; certifications, which usually indicate mastery of industry-defined competencies; and microcredentials, which are more narrowly focused than either certificates or certifications).

Steps in Introducing Sasakawa Africa Fund for Extension Education (SAFE) Demand Driven Curriculum to Universities

The following steps are implemented to introduce demand-driven curriculum to universities. 
Creative Commons User License: CC BY-NC-ND

Abstracted by: EBSCOhost, Electronic Journals Service (EJS),

Google Scholar, Journal Seek, Scientific Commons,

Food and Agricultural Organization (FAO), CABI and Scopus
Journal of Agricultural Extension

Vol. 25 (1) January, 2021

ISSN(e): 24086851; ISSN(Print); 1119944X

http://journal.aesonnigeria.org

http://www.ajol.info/index.php/jae

Email: editorinchief@aesonnigeria.org

Identify universities with expressed interest

1. Conduct need assessment

2. Organize stakeholders workshop for prioritization and validation of need assessment

3. Develop and sign MOU with universities and/agricultural colleges and relevant partners

4. Develop responsive curriculum

5. Review \& seek approval of curriculum

6. Develop relevant modules

7. Organize workshops for lecturers, partners and students on supervised enterprise projects (SEPs)

8. Advertise and enroll mid-career students

9. Establish enterprise centers and sign contractual agreements

10. Conduct supervised enterprise project

Carry out regular technical backstopping and visit

Table 1: List of SAFE demand-driven agricultural extension programmes in Nigeria

\begin{tabular}{|c|c|c|}
\hline University & Title of curriculum & Trainees \\
\hline Ahmadu Bello University Zaria & BSc Agriculture (Extension Services) & Mid-career \\
\hline Bayero University, Kano & $\begin{array}{l}\text { BSc Agricultural Extension and Community } \\
\text { Development }\end{array}$ & Mid-career \\
\hline $\begin{array}{l}\text { Adamawa State University, } \\
\text { Mubi }\end{array}$ & BSc. Agricultural Extension and Innovations & Mid-career \\
\hline $\begin{array}{l}\text { Usman Dan Fodio University } \\
\text { Sokoto }\end{array}$ & $\begin{array}{l}\text { BSc Agriculture (Dryland Farming } \\
\text { Extension) }\end{array}$ & Mid-career \\
\hline University of llorin & $\begin{array}{l}\text { BSc Agricultural Extension and Community } \\
\text { Development }\end{array}$ & Mid-career \\
\hline Federal University DutsinMa & BSc Agriculture Livestock Extension & Mid-career \\
\hline Obafemi Awolowo University & $\begin{array}{l}\text { BSc Agriculture (e-Extension and } \\
\text { Community Engineering) }\end{array}$ & Mid-career \\
\hline Bowen University & $\begin{array}{l}\text { B.Sc. Agricultural Extension and Social } \\
\text { Engineering }\end{array}$ & $\begin{array}{l}\text { Mid- career and } \\
\text { High school }\end{array}$ \\
\hline $\begin{array}{l}\text { Federal University Dutse } \\
\text { Jigawa }\end{array}$ & $\begin{array}{l}\text { BSc Agricultural Extension and Community } \\
\text { Development }\end{array}$ & Mid-career \\
\hline
\end{tabular}

Source: SAA, 2020.

\section{Conclusion and Recommendations}

To prevent the continual prevalence of skill mismatches that is currently dominating agricultural extension service delivery, there is the need to properly mainstream the use of demand-driven extension education strategies in training extension personnel. This is because the extension staff in a "generalist" or a "specialist" environment and system of practice require "hard" (technical) and "soft" (functional) skills; however, the functional skills should supersede, if the impact of innovation will lead to improved livelihoods of the beneficiaries. This is more important now than ever due 
Creative Commons User License: CC BY-NC-ND

Abstracted by: EBSCOhost, Electronic Journals Service (EJS),

Google Scholar, Journal Seek, Scientific Commons,

Food and Agricultural Organization (FAO), CABI and Scopus

http://eoi.citefactor.org/10.11226/v25i1
Journal of Agricultural Extension

Vol. 25 (1) January, 2021

ISSN(e): 24086851; ISSN(Print); 1119944X

http://journal.aesonnigeria.org

http://www.ajol.info/index.php/jae

Email: editorinchief@aesonnigeria.org

to the prevalence of the innovation system and the value-chain approach to extension services.

\section{References}

Berger, T. and C. Frey (2015), Future Shocks and Shifts: Challenges for the Global Workforce and Skills Development, OECD, http://www.oecd.org/education/2030project/about/documents/Future-Shocks-and-Shifts-Challenges-for-the-GlobalWorkforceand-Skills-Development.pdf.

Blumenstyk, G. (2019). Career-ready education: Beyond the skills gap, tools and tactics for an evolving economy. Washington, D.C.: The Chronicle of Higher Education

Cappelli, P. H. (2015). Skill gaps, skill shortages, and skill mismatches: Evidence and arguments for the United States. ILR Review, 68(2), 251-290.

Cho, Y., Robalino, D., and Watson, S. (2016) Supporting self-employment and small-scale entrepreneurship: potential programs to improve livelihoods for vulnerable workers IZA Journal of Labor Policy 5:7 DOI 10.1186/s40173-016-0060-2

Davis, K. E. (2015). The new extensionist: Core competencies for individuals. GFRAS Brief \#3. Lindau, Switzerland: Global Forum for Rural Advisory Services (GFRAS).

Deegan, J., and Martin, N. (2017). Merging work \& learning to develop the human skills that matter. Available online at http://www.echs-nm.com/wpcontent/uploads/2019/10/DDE Pearson Report 3.pdf

European Commission (2015) "Measuring Skills Mismatch", European Commission Analytical Web Note 7/2015. Available at https://ec.europa.eu

Figg, C., Wenrick, M., Youker, C., Heilman, J., and Schneider, C. (2020) Implications and Benefits of a Long-Term. Peer Debriefing Experience on Teacher Researchers. Brock Education, Volume 19, No. 1, Fall 2010, 20-35 20.

Gambin, L., Hogarth, T., Murphy, L., Spreadbury, K., Warhurst, C., and Winterbotham, M. (2016). Research to understand the extent, nature and impact of skills mismatches in the economy: BIS research paper 265. Department for Business, Innovation and Skills, London

Gates L. (2015). "Our Big Bet for the Future" Bill and Melinda Gates 2015 Annual Letter. Available online at http://www.gatesfoundation.org/Media-Center/PressReleases/2015/01/2015-Annual-Letter.

Ghimire, R. P. (2017) Extension Professionals Preparedness for Demand-Driven Agriculture Extension Services in Nepal. Journal of Extension Systems 33(01). DOl: $\underline{10.18765 / j e s . v 33 i 01.10580}$

Hailemichael, S. and Haug, R. (2020) The use and abuse of the 'model farmer' approach in agricultural extension in Ethiopia, The Journal of Agricultural Education and Extension, 26:5, 465-484, DOI: 10.1080/1389224X.2020.1757475 
Creative Commons User License: CC BY-NC-ND

Abstracted by: EBSCOhost, Electronic Journals Service (EJS), Google Scholar, Journal Seek, Scientific Commons,

Food and Agricultural Organization (FAO), CABI and Scopus

http://eoi.citefactor.org/10.11226/v25i1
Journal of Agricultural Extension

Vol. 25 (1) January, 2021

ISSN(e): 24086851; ISSN(Print); 1119944X

http://journal.aesonnigeria.org

http://www.ajol.info/index.php/jae

Email: editorinchief@aesonnigeria.org

Indian Council of Agricultural Research (ICAR) (2017). Report of the Fifth Deans Committee on Agricultural Education in India. Indian Council of Agricultural Research, New Delhi. Available at http://www.icar.org.in/files/FifthDeansCommiteeReport-22022017.pdf

Kalule, S.W., Sseguya, H., Ongeng, D. and Karubanga, G. (2019) Facilitating conditions for farmer learning behaviour in the student-to-farmer university outreach, The Journal of Agricultural Education and Extension, 25:3, 211225, DOI: $\underline{10.1080 / 1389224 X .2019 .1604389}$

Kaur, S., Kremer, M., and Mullainathan, S. (2015). Self-control at work. Journal of Political Economy, 123(6), 1227-1277.

Khondokar H. K, Knierim, A., and Chowdhury, A. (2020) Assessment of a pluralistic advisory system: the case of Madhupur Sal Forest in Bangladesh. The Journal of Agricultural Education and Extension 26:3, pages 307-330.

Kojima, F., Sun, N. and Yu, N. N. (2020). "Job Matching under Constraints." American Economic Review, 110 (9): 2935-47.DOI: 10.1257/aer.20190780

Marginson, S. (2019) Limitations of human capital theory, Studies in Higher Education, 44:2, 287-301, DOI: 10.1080/03075079.2017.1359823

McGuinness, S., and Ortiz, L. (2016). Skill gaps in the workplace: measurement, determinants and impacts. Industrial relations journal, 47(3), 253-278.

Montt, G. (2017). Field-of-study mismatch and overqualification: labour market correlates and their wage penalty. IZA J Labor Econ 6, 2. https://doi.org/10.1186/s40172-0160052-

Oladele, O. I. (2019). Private sector and sustainable agricultural development: the pervasiveness qualitative and quantitative skills mismatch in agricultural advisory services in Africa", 4th Africa-wide Agricultural Extension Week in Abidjan, Côte d'Ivoire. 25th - 28th November 2019.

Organisation for Economic Co-Operation and Development (OECD) (2016). Skills matter: further results from the Survey of Adult Skills. OECD Publishing, Paris, doi:10.1787/9789264258051-en

OECD (2018), The Future of Education and Skills: Education 2030. Position paper, http://www.oecd.org/education/2030/E2030\%20Position\%20Paper\%20(05.04.2018).pdf

Ragasa, C., and Mazunda, J. (2018). The impact of agricultural extension services in the context of a heavily subsidized input system: The case of Malawi. World development, $105,25-47$.

Santos, K. S., Ribeiro, M. C., Queiroga, D. E. U., Silva, I. A. P., and Ferreira, S. M. S. (2020) The use of multiple triangulations as a validation strategy in a qualitative 
Creative Commons User License: CC BY-NC-ND

Abstracted by: EBSCOhost, Electronic Journals Service (EJS), Google Scholar, Journal Seek, Scientific Commons,

Food and Agricultural Organization (FAO), CABI and Scopus

http://eoi.citefactor.org/10.11226/v25i1
Journal of Agricultural Extension

Vol. 25 (1) January, 2021

ISSN(e): 24086851; ISSN(Print); 1119944X

http://journal.aesonnigeria.org

http://www.ajol.info/index.php/jae

Email: editorinchief@aesonnigeria.org

study. Ciência \& Saúde Coletiva, 25(2), 655-664. Epub February 03, 2020.https://doi.org/10.1590/1413-81232020252.12302018

Sasakawa Africa Association (SAA) (2020). Sasakawa Africa Association Strategic plan 2017-2023

Sasakawa Africa Association (SAA) (2018). Sasakawa Africa Association Annual Report

Schweri, J., Eymann, A., and Aepli, M. (2020) Horizontal mismatch and vocational education, Applied 3478, DOI: $\underline{10.1080 / 00036846.2020 .1713292}$

Economics, 52:32, 3464-

Stoevska, V. (2017). Qualification and Skill Mismatch: Concept and Measurement. ILO International Conference on jobs and Skills Mismatch May 11-12, 2017, Geneva, Switzerland

Suvedi, M., Ghimire, R., and Channa, T. (2018). Examination of core competencies of agricultural development professionals in Cambodia. Evaluation and program planning, 67, 89-96.

Society for Human Resource Management (SHRM) (2016). Employee Job Satisfaction and Engagement: Revitalizing a Changing Workforce. A Research Report by the Society for Human Resource Management. Available at https://www.shrm.org/hr-today/trends-andforecasting/research-and-surveys/Documents/2016-Employee-Job-Satisfaction-andEngagement-Report.pdf

Uh S. B., Jo, S. Y., and Kim, D. K. (2015). Research report for improvement of standard for vocational trainers' qualification system. Korea University of Technology and Education

Winfrey, M. (2015). Agricultural Education and Training Must be Local and Demand-Driven. AGRILINKS: Innovation for Agricultural Training and Education(INNOVATE). Available online at: https://www.agrilinks.org/blog/agricultural-education-and-training-must-belocal-and-demand-driven

World Bank, (2015). For Up to 800 Million Rural Poor, a Strong World Bank Commitment to Agriculture Available at http://www.worldbank.org/en/news/feature/2014/11/12/for-up-to800-million-rural-poor-a-strong-world-bank-commitment-to-agriculture 